\title{
Transplantation of melanocyte stem cells in vitiliginous skin
}

\author{
Yohanes Widodo Wirohadidjojo* and Flandiana Yogianti* \\ *Department of Dermatology and Venereology, Faculty of Medicine, Universitas Gadjah \\ Mada/ Dr. Sardjito General Hospital, Yogyakarta, Indonesia
}

DOI: http://dx.doi.org/10.19106/JMedSci004704201503

\begin{abstract}
Depigmentation in vitiligo occurs as a result of progressive loss of functioning epidermal melanocytes, and currently various modalities have been developed to re-functioning these cells. However, in area with poor melanocytes reservoir, such as old-persistent lesions or lesions on bony prominence, the modalities are hardly to achieve repigmentation. Since spontaneous repigmentation of vitiliginous skins begin mostly in follicular areas, reactivation of melanocyte precursors along the outer root sheath of hair follicle is expected to have better on this pigmentation. Melanocyte precursor came from melanocyte stem cells that originally located on bulge area of hair follicles. The latest surgical intervention in vitiligo is transplantation of melanocyte stem cells. Clinical experiments indicated that the transplantation can be performed either by transplantation of extracted follicular units or single cell suspension harvested from this area. By single cell suspension treatment, a $50 \mathrm{~cm}^{2}$ of vitiliginous skin can be handled by 15 autologous hair follicular units. These procedures are easy and can be performed by any dermatologist especially who has been trained in dermatologic surgery as well as in cellular based therapies.
\end{abstract}

\section{ABSTRAK}

Depigmentasi pada vitiligo terjadi akibat kehilangan secara progesif fungsi melanosit epidermal dan saat ini berbagai modalitas telah dikembangkan untuk mengembalikan fungsi sel. Namun demikian, daerah dengan sumber melanosit yang rendah seperti lesi persisten yang lama atau lesi pada tonjolan tulang, modalitas tersebut sulit mengalami repigmentasi. Sejak repigmentasi spontan kulit vitiliginus mulai terutama di daerah folikel, reaktivasi pekusor melanosit sepanjang selubung akar luar folikel rambut diharapan proses pigmentasi berjalan lebih baik. Prekusor melanosit berasal dari sel punca melanosit yang terletak di area tonjolan folikel rambut. Intervensi bedah paling akir pada vitiligo adalah transplantasi sel punca melanosit. Pengalaman klinik menunjukkan bahwa transplantasi dapat dilakukan baik dengan transplantasi unit folikel yang diekstrak atau suspensi sel tunggal yang diambil dari area ini. Dengan pengobatan suspensi sel tunggal, $50 \mathrm{~cm}^{2}$ kulit vitiligo dapat dilakukan oleh 15 unit folikel rambut autolog. Prosedur ini mudah dan dapat dilakukan oleh dokter spesialis kulit dan kelamin yang telah dilatih dalam bedah kulit juga pengobatan berbasi sel.

Keywords: Vitiligo, Melanocyte stem cells, extracted hair follicular, single cell suspensions 


\section{INTRODUCTION}

As, vitiligo is an acquired pigmentation disorder manifested with development of white macules or patches on affected skin due to a progressive loss of functioning of epidermal melanocytes. The basic mechanism has not yet been clearly identified, however, various mechanisms have been proposed, including genetic association, ${ }^{1,2}$ autoimmunity and oxidative stress, ${ }^{3-5}$ neurohormonal imbalance, ${ }^{6}$ abnormalities in the microenvironment surrounding the melanocytes ${ }^{7-9}$ and intrinsic defects of melanocytes and periphery $\mathrm{T}$ cell regulator which promote innate immune attack. ${ }^{10,11}$

Various modalities have been developed to treat vitiliginous skins, among others : a) anti-oxidant agents such as: Polypodium leucotomos as adjunct therapy with PUVA, ${ }^{12}$ or fish oil ${ }^{13}$; b) immunosuppressive agents such as: topical corticosteroid, ${ }^{14}$ tacrolismus, ${ }^{15-17}$ or calcipotriol, ${ }^{18,19}$ either used as single modality or in combination with NB-UVB or excimer laser; c) UVA light combined with photosensitizer agent such as: psoralen, ${ }^{20,21}$; d) oral minocycline ${ }^{22,23}$ which nevertheless less effective than NB-UVB. ${ }^{24}$ Previous study showed that minocycline could protect melanocytes from $\mathrm{H}_{2} \mathrm{O}_{2}$-induced cell death. ${ }^{25}$ Systematic review revealed that NB-UVB showed equivalent therapeutic efficacies to UVA, PUVA or 308-nm Excimer Laser, in $>50 \%$ and $>75 \%$ of repigmentation. ${ }^{26}$ However, these modalities have limitations, especially in achieving total repigmentation. In facts, failure of repigmentation is usually found among old-persistent lesions or lesions on skin over the bony prominences with poor melanocytes reservoir. Cui et al., ${ }^{27}$ reported that spontaneous repigmentation of vitiligo usually begins as multiple dots of pigmentation around of hair follicle areas where they are rich with melanocytes reservoir. Since human epidermal melanocytes stem cells can be found along bulge area of hair follicles, and follicle unit extractions method has been developed by trichologists where part of the bulge area is also involved, transplantation of melanocyte stem cells is now become possible. Here, the basic technique of this modality, and method of transplantation is described.

\section{MELANOCYTE STEM CELLS \\ Characteristic of Melanocyte Stem Cells}

Stem cells are defined as cells that able to self-renew so they can divide and maintain their population and provide specialized and differentiated daughter cells of their specific tissue type. ${ }^{28,29}$ In addition, the degree of plasticity and the markers expressed is different between adult and embryonic stem cells, as well as between adult stem cells of different tissue types. Stem cells are present in an environment as a special cellular organization called the niche. ${ }^{30,31}$ The signals within niche has important factor in regulation of stem cell's self-renewing and differentiation. ${ }^{32,33}$

Melanocyte stem cells (MSCs) were first identified in the hair follicle and are located in the bulge region as their niche (FIGURE 1). ${ }^{34}$ They differentiate into hair follicle melanocytes at the beginning of anagen phase and undergo apoptosis at catagen phase. ${ }^{35}$

MSCs are generated from melanoblasts that populate the hair follicle bulge, and they are stimulated to become inactive by their niche at the final stage of hair follicle morphogenesis. $^{36,37}$ The responsible niche for this purpose is signaling of transforming growth factor $\beta$ (TGF- $\beta$ ) by inducing cell cycle arrest, down-regulation of MITF (Microphthalmia-Associated Transcription Factor) gene expression, and suppression of melanogenic genes in melanoblasts. 


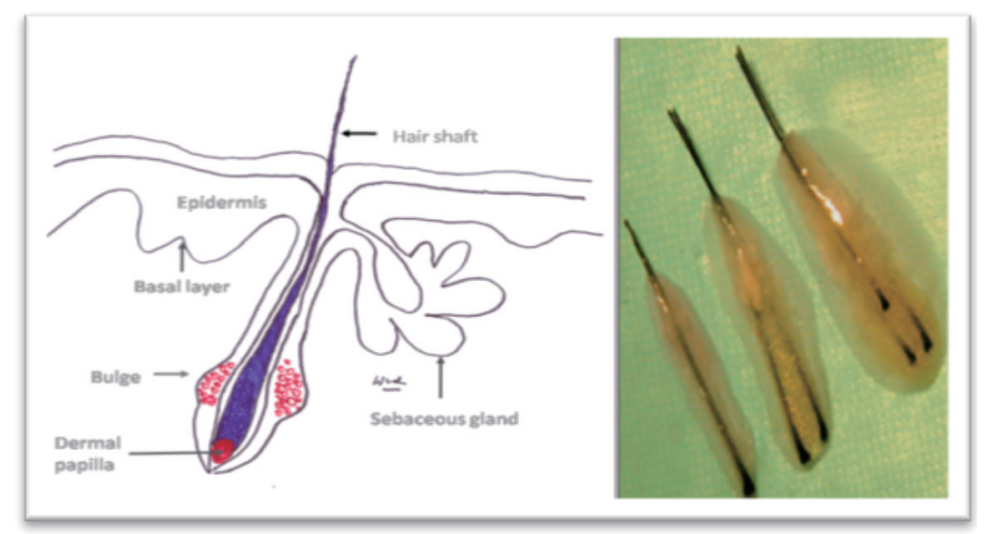

FIGURE 1. Location of MSCs along hair follicle (left), and extracted hair follicle unit (right)

Signaling TGF- $\beta$ through TGF- $\beta$ RII is also as key role in regulation melanocyte stem cell immaturity and quiescence. ${ }^{38}$ Both states of immaturity and quiescent is important factor for maintenance MSCs population during growing phase of hair cycle. In this condition, $B c l 2$, an anti-apoptotic factor, is essential for survival of MSCs during this phase. ${ }^{37,38}$ MITF gene product, namely MITF, is also an important transcription factor to prevent premature MSCs differentiation and pigmentation. ${ }^{38}$ Hair graying, as one phenotype of human aging, occurs as a result of loss of hair follicle melanocytes which is caused by gradual loss of MSCs..$^{37,39}$ Loss of MSCs is caused by failure of MSCs maintenance in the bulge region of hair follicles. ${ }^{37}$ Inappropriate maintenance of MSCs results in the failure of MSCs to proliferate and differentiate, migrate to wrong places, or death. ${ }^{39}$ All of these events are related to TGF- $\beta$ signaling. Other studies indicated that TGF- $\beta$ production and TGF- $\beta$ RII expression is down-regulated among aged skin..$^{40,41}$

\section{Isolation and cultivation of MSCs}

The best source of MSCs is hair follicles, especially the outer root sheats of hair follicles. These cells can be propagated to multiply by explant method, ${ }^{42}$ but the hair shaft must be plug out together with dermal papilla because dermal papilla is an important niche for epidermal stem cells, including MSCs. $^{43,44}$ For this purpose, follicular unit extraction (FIGURE-1) either by using minipunch instrument or micro motorized mini punch is considered as the best method. ${ }^{45}$ This technique allows the hair of donor sites to regrowth with the absence or minimal scarring. Furthermore, extracted follicular unit contains dermal papilla together with a part of bulge area. ${ }^{46}$ Cultivation of extracted follicular unit can be done by using stem cellmedium. ${ }^{42}$ In the Dermatology Department Universitas Gadjah Mada, cellular expanding with melanin production can be obtained by Dulbecco's minimal essential media (DMEM) supplemented with $10 \%$ fetal bovine serum (FIGURE 2). 


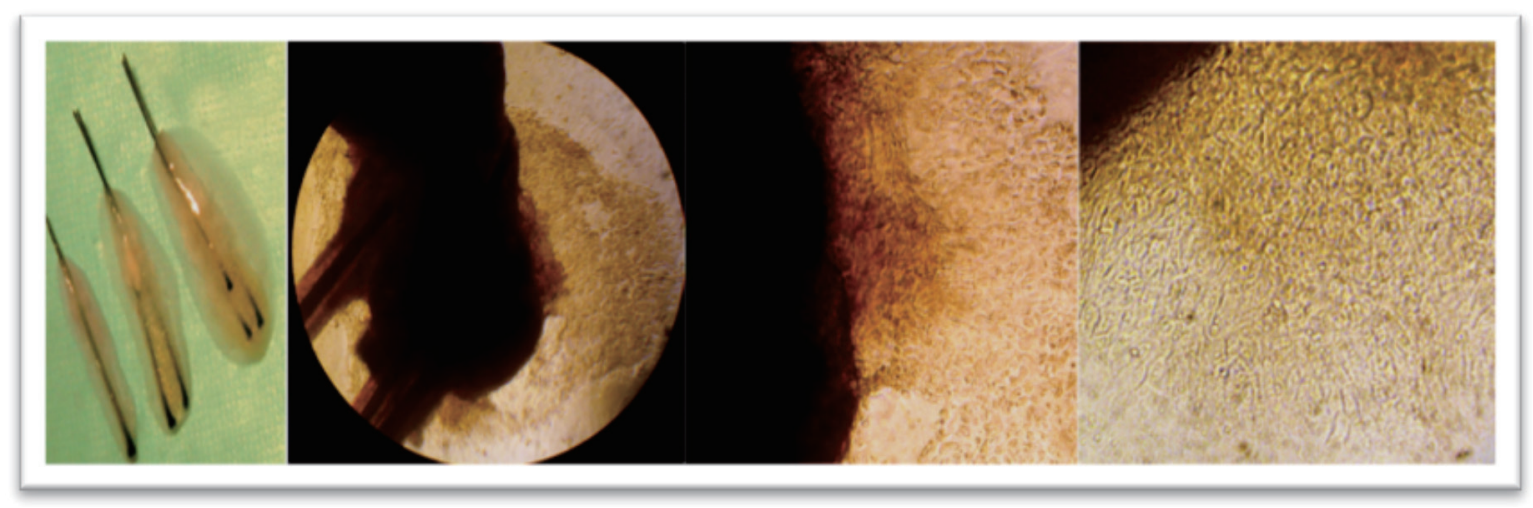

FIGURE 2. Culture expansion of melanin-producing cells from extracted hair follicles

A single cell suspension can be obtained from extracted hair follicles by simple trypsin digestion and cultured in melanocyte growth medium with stem cell factor. To maintenance their proliferation rates, a second passage of keratinocytes must be added into culture dish as feeder layer, after day $21 .{ }^{47}$ In this method, beside of MSCs, neural crest stem cells (NCSCs) can also be alternative as concomitant culture. ${ }^{48}$

\section{MSCs in vitiligo}

Controversy of totally loss or inactivation state of MSCs of vitiliginous lesion has existed for a long time. In order to get certain answer for this problem, Seleit et al., ${ }^{49}$ evaluated the MSCs-lineage in follicular and inter-follicular vitiliginous epidermis through immunohistochemical localization of Human MelanomaBlack-45(HMB-45) and Tyrosinase Related Protein 2 (TRP2). They found that MSCs were detected in $44 \%$ of inter-follicular epidermis and $46.7 \%$ of follicular epidermis of vitiliginous lesions. Melanocyte precursors were detected in $54 \%$ of inter-follicular and $63.3 \%$ of follicular in skin lesions. The existence of MSCs and melanocyte precursors was higher among black hair than white hair of vitiliginous lesions. This finding indicates that killing melanocytes by innate immune attack is not directing against MSCs, but into mature melanocytes. This finding also supports previously hypothesis that failure of re-pigmentation of vitiliginous lesions is located in skin area with poor hair follicles. ${ }^{50}$

The presence MSCs on vitiliginous lesions may be caused by elevation of serum level of TGF- $\beta$, as it has been described on above. Serum level of TGF- $\beta$ of non-segmental vitiligo is indeed elevated. ${ }^{51,52}$ Conversely, this elevation is responsible for failure residual melanocytes in producing melanin as it has been discovered by Kim et al., ${ }^{53}$ When autologous MSCs from normal skin planned to elevate numbers of precursor melanocytes in vitiliginous lesions, those transplanted MSCs must receive special treatment so that inhibition of melanin production by TGF- $\beta$ can be minimize. Blocking TGF- $\beta$ RII expression can be achieved by giving ultraviolet irradiation onto vitiliginous lesions after MSCs transplantation. ${ }^{54,55}$ Study conducted among neonatal mouse skin indicated that repeated ultraviolet $B$ (UVB) irradiation can induce MSCs differentiation into melanocytes and melanin production. ${ }^{56}$ Broad band UVB showed a better efficacy in awakening MSCs than narrow band UVB. ${ }^{57}$ Similar event also happened among hair follicles and the epidermis of human vitiliginous skins. ${ }^{58}$ 


\section{MELANOCYTES STEM CELLS TRANSPLANTATION VITILIGINOUS LESIONS \\ ON}

\section{Principle of surgical interventions}

The basic principle of surgical treatment in vitiligo is to achieve cosmetically acceptable repigmentation of the vitiliginous areas by transplantation of autologous melanocytes or MSCs from the unaffected pigmented skin to the vitiliginous skins. Surgical intervention cannot stop the progression of this disease, therefore this technique is only indicated for stable vitiligo that does not show adequate response to medical therapies. ${ }^{59}$ Although there is no universal consensus on how to define stable vitiligo, the Indian Association of Dermatology, Venereology and Leprology (IADVL) establish a consensus recommendations to define this stability that is a patient reporting no new lesions, no progression of existing lesions, and absence of Koebner phenomenon during the past one year. ${ }^{60}$

There are various methods of surgical intervention for vitiliginous skin, some of those techniques are attempted to transplant melanocytes from the donor to the recipient areas, such as: suction blister grafting, thin epidermal grafting, and mixed epidermal cell suspensions grafting, ${ }^{61}$ whereas others may provide melanocytes, melanocyte precursors, and also MSCs, such as: hair follicular grafting and mini-punch grafting. Among hair follicular grafting which is harvested by follicular unit extractions, the grafts are composed by hair shaft, a part of hair bulge where MSCs are located, and dermal papilla as niche of MSCs and other epidermal stem cells.

\section{Hair Follicle Unit Extractions (FUE)}

Before FUE was developed in hair transplantation surgery, follicular unit transplantation was obtained from hairy skin stripping followed by stereo-microscopic dissections. This strip-harvesting technique caused donor scarring on occipital area which sometimes are difficult to be covered by surrounding hair. FUE was firstly introduced by Rasmann et al., ${ }^{62}$ who used one-millimeter punch to insulate follicular units from the surrounding tissues down to the level of the mid dermis then followed by extractions of these units with forceps. By this method, scarring due to single strip harvesting does not occur and microscopic dissections are not needed. In addition, by leaving a part of bulge area in punched holes, hair shaft can regrowth and hair density on donor area is not markedly disturbed $^{46}$ (FIGURE 3). Furthermore, in order to increase survival rate of harvested grafts, Senthi et al., ${ }^{63}$ modified FUE hair transplantation by implanting FUEs as soon as they were harvested and this technique showed a better results in hair transplantation. 

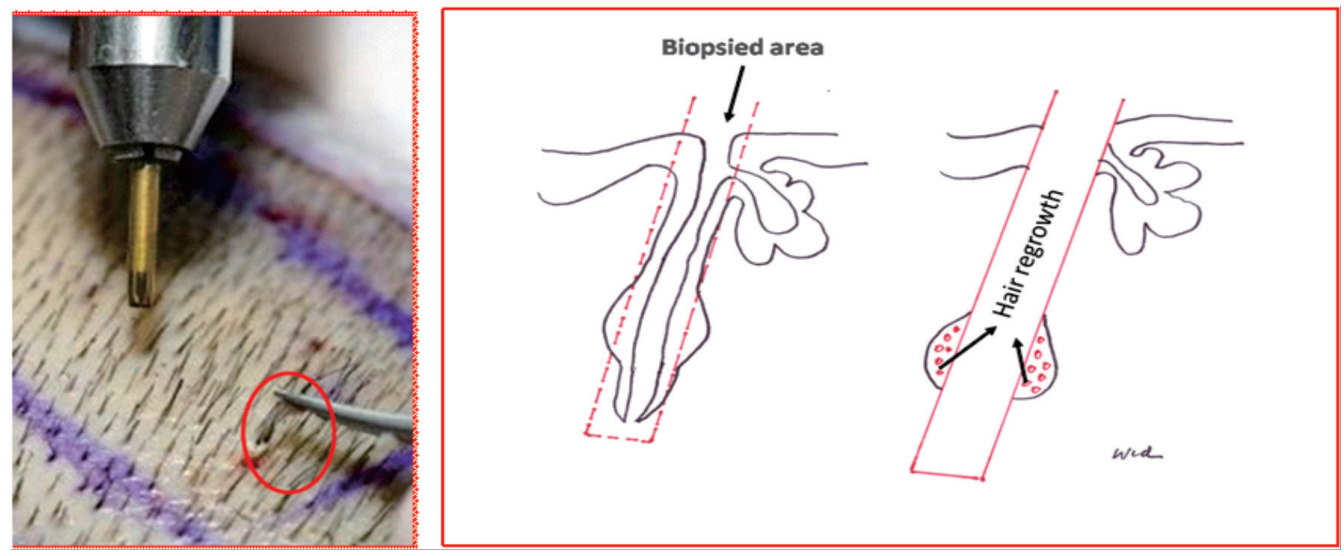

FIGURE 3. Follicular Unit Extraction Follicular unit extraction (red-circle) (left), leave a part of bulge area as a source for hair regrowth (right)

\section{Aplication FUE onto Vitiliginous Skin}

Directapplication of autograft hair follicles onto vitiliginous skin has been reported by many authors. Recipient area must be nonhairy areas otherwise hair removal treatment must be performed afterward. Transplantation of FUE onto the right eyebrow of eight years duration of 12 years old female was reported by Sacchidanand et al. ${ }^{64}$ which procedure was easy, scarless and sutureless, but seemly only for small size of stable vitiligo. Aziz Jalani et al., ${ }^{65}$ reported that occipital hair follicles transplantation, harvested by punch biopsy instrument then dissected to various follicular units can induce repigmentation of persistent segmental vitiligo among 10 patients. FUE can be harvested from hair body or scalp areas and FUE from this region indicate same characteristic with FUE from scalp area, such as reported by Chouhan et al., ${ }^{66}$ when they successfully transplanted FUE from the right upper thigh to the left shin, calves and both ankles vitiliginous skin. Repigmentation rates of hair follicles transplantation is equal with those achieved by multiple mini punch grafts, however mini punch grafting is much easier and the procedure is faster than hair follicles transplantation method. Based on this finding, Mapar et al., ${ }^{67}$ suggested to perform multiple mini punch grafts for stable vitiligo. In Department of Dermatology and Venereology Sardjito General Hospital, we performed multiple mini punch grafts from the left upper thigh skin with vellus hairs and transplanted onto the left eyebrow of 17 years old female of a Sardjito Hospital's segmental vitiligo patient as additional procedure of suction blister grafting (FIGURE 4). 

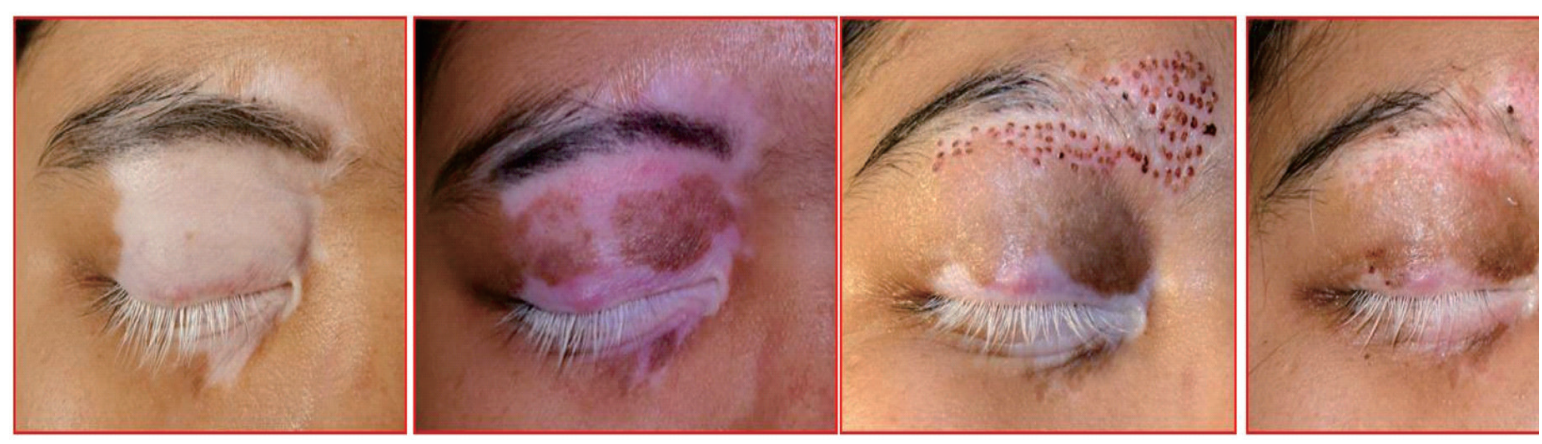

FIGURE 4. Mini punches graft from vellus hairs area onto eyebrow area as additional procedure after suction blister grafting of a Sardjito Hospital's patient (From left to right side: before procedure, a week after suction blister grafting, vellus hair mini punch grafts, a week later)

Except for hairy areas, another limitation of FUE transplantation is convenient only in small areas of skin. For larger areas, FUE transplantation must be modified to become hair follicle cell suspensions so that it can be sprayed onto large dermabraded vitiliginous skin, similar to mixed epidermal cell suspensions grafting method. The advantages of this technique are the amount of MSCs and melanocytes precursor collected in this suspension. Preparation of extracted hair follicle outer root sheath cell suspension can refer to the method of Kumar et al. ${ }^{68} \mathrm{By}$ simple warm trypsin digestion of extracted hair follicle units, a large number of mixed cells can be obtained (FIGURE 5).

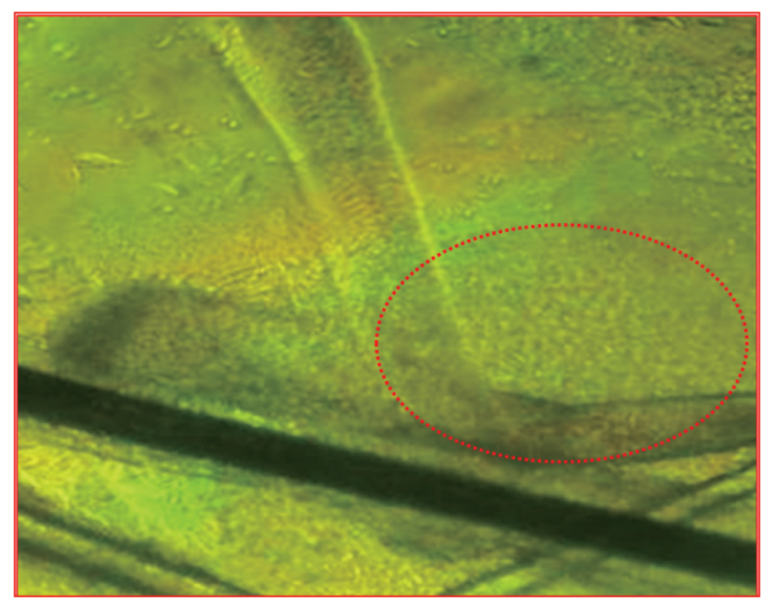

FIGURE 5. Enzymatic digestion of bulge area (redcircle) of extracted hair follicle units.

Enzymatic digestion by trypsin must be performed for at least 90 minute in $37^{\circ} \mathrm{C}$. In the next step, cell suspension collected from this procedure can be sprayed onto dermabraded vitiliginous skin after removing the residual trypsin. A number of 15 hair follicles can be used to cover $30.8 \pm 26.5 \mathrm{~cm}^{2}$ and the repigmentation rates can be around $65.7 \pm$ $36.7 \% .^{68}$ Another advantage of this procedure is resistance of transferred melanocyte stem 
cells from innate immune attack as one of basic mechanism of vitiligo. ${ }^{69}$

\section{CONCLUSION}

Loss of functioning epidermal melanocytes which cause depigmentation of vitiliginous skin can be ameliorated by MSCs transplantation. Bulge area of hair follicle is a rich source of MSCs and transplantation of MSCs can be performed by FUE of hair transplantation especially on haired skin with limited affected areas. For larger area, spraying cell suspension of extracted follicular unit on to dermabraded area is believed to be the best choice.

\section{ACKNOWLEDGEMENTS}

Authors would like to thank Prof. Hardjanto Soebono who has reviewed this article.

\section{REFERENCES}

1. Spritz RA. Six decades of vitiligo genetics: genome-wide studies provide insights into autoimmune pathogenesis. J Invest Dermatol 2012; 132(2):268-73.

2. Czajkowski R, Męcińska-Jundziłł K. Current aspects of vitiligo genetics. Postepy Dermatol Alergol 2014; 31(4):247-55.

3. Nejad SB, Qadim HH, Nazeman L, Fadaii R, Goldust M. Frequency of autoimmune diseases in those suffering from vitiligo in comparison with normal population. Pak J Biol Sci 2013; 16(12):570-4.

4. Laddha NC, Dwivedi M, Mansuri MS, Singh M, Gani AR, Yeola AP, et al. Role of oxidative stress and autoimmunity in onset and progression of vitiligo. Exp Dermatol 2014; 23(5):352-3.

5. Yildirim M, Baysal V, Inaloz HS, Kesici D, Delibas N. The role of oxidants and antioxidants in generalized vitiligo. J Dermatol 2003; 30(2):104-8.

6. Haycock JW, Rowe SJ, Cartledge S, Wyatt A, Ghanem G, Morandini R, et al. Alphamelanocyte-stimulating hormone reduces impact of proinflammatory cytokine and peroxidegenerated oxidative stress on keratinocyte and melanoma cell lines. J Biol Chem 2000; 275(21):15629-36.

7. Moretti S, Fabbri P, Baroni G, Berti S, Bani $\mathrm{D}$, Berti E, et al. Keratinocyte dysfunction in vitiligo epidermis: cytokinemicroenvironment and correlation to keratinocyte apoptosis. Histol Histopathol 2009; 24(7):849-57.

8. Camara-Lemarroy CR, Salas-Alanis JC. The role of tumor necrosis factor- $\alpha$ in the pathogenesis of vitiligo. Am J Clin Dermatol 2013; 14(5):343-50.

9. Seif El Nasr H, Shaker OG, Fawzi MM, ElHanafi G. Basic fibroblast growth factor and tumour necrosis factor alpha in vitiligo and other hypopigmented disorders: suggestive possible therapeutic targets. J Eur Acad Dermatol Venereol 2013; 27(1):103-8.

10. Richmond JM, Frisoli ML, Harris JE. Innate immune mechanisms in vitiligo: danger from within. Curr Opin Immunol 2013; 25(6):67682.

11. Ben Ahmed M, Zaraa I, Rekik R, ElbeldiFerchiou A, Kourda N, Belhadj Hmida N, et al. Functional defects of peripheral regulatory $\mathrm{T}$ lymphocytes in patients with progressive vitiligo. Pigment Cell Melanoma Res 2012; 25(1):99-109.

12. Nestor M, Bucay V, Callender V, Cohen JL, Sadick N, Waldorf H. Polypodium leucotomos as an Adjunct Treatment of Pigmentary Disorders. J Clin Aesthet Dermatol 2014; 7(3):13-7.

13. Ghorbanibirgani A, Khalili A, Rokhafrooz D. Comparing nigella sativa oil and fish oil in treatment of vitiligo. Iran Red Crescent Med J 2014; 16(6):4515. 
14. de la Fuente-García A, Gómez-Flores M, Mancillas-Adame L, Ocampo-Candiani J, Welsh-Lozano O, Pérez JZ, et al. Role of the $\mathrm{ACTH}$ test and estimation of a safe dose for high potency steroids in vitiligo: A prospective randomized study. Indian Dermatol Online J 2014; 5(2):117-21.

15. Sahni K, Gupta V, Khanna N. Hyperpigmentation in photo exposed patches of vitiligo following tacrolimus therapy. Indian Dermatol Online J 2014; 5(2):164-6.

16. Matin M, Latifi S, Zoufan N, Koushki D, Mirjafari Daryasari SA, Rahdari F. The effectiveness of excimer laser on vitiligo treatment in comparison with a combination therapy of Excimer laser and tacrolimus in an Iranian population. J Cosmet Laser Ther 2014; 16(5):241-5.

17. Wong R, Lin AN. Efficacy of topical calcineurin inhibitors in vitiligo. Int $\mathrm{J}$ Dermatol 2013; 52(4):491-6.

18. Akdeniz N, Yavuz IH, Gunes Bilgili S, Ozaydın Yavuz G, Calka O. Comparison of efficacy of narrow band UVB therapies with UVB alone, in combination with calcipotriol, and with betamethasone and calcipotriol in vitiligo. J Dermatolog Treat 2014; 25(3):1969.

19. Khullar G, Kanwar AJ, Singh S, Parsad D. Comparison of efficacy and safety profile of topical calcipotriol ointment in combination with NB-UVB vs. NB-UVB alone in the treatment of vitiligo: a 24-week prospective right-left comparative clinical trial. J Eur Acad Dermatol Venereol 2014; 29(5):925-32.

20. Singh S, Khandpur S, Sharma VK, Ramam M. Comparison of efficacy and side-effect profile of oral PUVA vs. oral PUVA sol in the treatment of vitiligo: a 36-week prospective study. J Eur Acad Dermatol Venereol 2013; 27(11):1344-51.

21. El Mofty M, Bosseila M, Mashaly HM, Gawdat H, Makaly H. Broadband ultraviolet
A vs. psoralen ultraviolet $\mathrm{A}$ in the treatment of vitiligo: a randomized controlled trial. Clin Exp Dermatol 2013; 38(8):830-5.

22. Parsad D, Kanwar A. Oral minocycline in the treatment of vitiligo--a preliminary study. Dermatol Ther 2010; 23(3):305-7.

23. Singh A, Kanwar AJ, Parsad D, Mahajan R. Randomized controlled study to evaluate the effectiveness of dexamethasone oral minipulse therapy versus oral minocycline in patients with active vitiligo vulgaris. Indian J Dermatol Venereol Leprol 2014; 80(1):29-35.

24. Siadat AH, Zeinali N, Iraji F, Abtahi-Naeini $\mathrm{B}$, Nilforoushzadeh MA, Jamshidi $\mathrm{K}$, et al. Narrow-Band Ultraviolet B versus oral minocycline in treatment of unstable vitiligo: a prospective comparative trial. Dermatol Res Pract 2014; 240856.

25. Song X, Xu A, Pan W, Wallin B, Kivlin R, $\mathrm{Lu} \mathrm{S}$, et al. Minocycline protects melanocytes against $\mathrm{H} 2 \mathrm{O} 2$-induced cell death via JNK and p38 MAPK pathways. Int J Mol Med 2008; 22(1):9-16.

26. Xiao BH, Wu Y, Sun Y, Chen HD, Gao $\mathrm{XH}$. Treatment of vitiligo with NB-UVB: A systematic review. J Dermatolog Treat. 2014; 26(4):340-6.

27. Cui J, Shen LY, Wang GC. Role of hair follicles in the re-pigmentation of vitiligo. $\mathrm{J}$ Invest Dermatol 1991; 97(3):410-6.

28. Hall PA, Watt FM. Stem cells: the generation and maintenance of cellular diversity. Development 1989; 106(4):619-33.

29. Potten CS, Loeffler M. Stem cells: attributes, cycles, spirals, pitfalls and uncertainties. Lessons for and from the crypt. Development 1990; 110(4):1001-20.

30. Watt FM, Hogan BL. Out of Eden: stem cells and their niches. Science 2000; 287(5457):1427-30.

31. Li L, Xie T. Stem cell niche: Structure and function. Annu Rev Cell Dev Biol 2005; 21:605-31. 
32. Lander AD, Kimble J, Clevers H, Fuchs E, Montarras D, Buckingham M, et al. What does the concept of the stem cell niche really mean today? BMC Biol 2012; 10:19.

33. Chen S, Lewallen M, Xie T. Adhesion in the stem cell niche: biological roles and regulation. Development 2013; 140(2):25565.

34. Sarin KY, Artandi SE. Aging, graying and loss of melanocyte stem cells. Stem Cell Rev 2007; 3(3):212-17.

35. Robinson KC, Fisher DE. Specification and loss of melanocyte stem cells. Semin Cell Dev Biol 2009; 20(1):111-16.

36. Nishimura EK, Jordan SA, Oshima H, Yoshida $\mathrm{H}$, Osawa M, Moriyama M, et al. Dominant role of the niche in melanocyte stem-cell fate determination. Nature 2002; 416(6883):85460.

37. Nishimura EK, Granter SR, Fisher DE. Mechanisms of hair graying: Incomplete melanocyte stem cell maintenance in the niche. Science 2005; 307(5710):720-4.

38. Nishimura EK, Suzuki M, Igras V, Du J, Lonning S, Miyachi Y, et al. Key roles for transforming growth factor $\beta$ in melanocyte stem cell maintenance. Cell stem cell 2010; 6(2):130-40.

39. Gola M, Czajkowski R, Bajek A, Dura A, Drewa T. Melanocyte stem cells: biology and current aspects. Med Sci Monit 2012; 18(10):155-9.

40. Fisher GJ, Kang S, Varani J, Bata-Csorgo Z, Wan Y, Datta S, et al. Mechanisms of photoaging and chronological skin aging. Arch Dermatol 2002; 138(11):1462-70.

41. Quan T, He T, Voorhees JJ, Fisher GJ. Ultraviolet irradiation blocks cellular responses to transforming growth factor- $\beta$ by down-regulating its type-II receptor and inducing Smad7. J Biol Chem 2001; 276(28):26349-56.
42. Yu H, Fang D, Kumar SM, Li L, Nguyen TK, Acs $\mathrm{G}$, et al. Isolation of a novel population of multipotent adult stem cells from human hair follicles. Am J Pathol 2006; 168(6):1879-88.

43. Rendl M, Lewis L, Fuchs E. Molecular dissection of mesenchymal-epithelial interactions in the hair follicle. PLoS Biol 2005; 3(11):331.

44. Rendl M, Polak L, Fuchs E. BMP signaling in dermal papilla cells is required for their hair follicle-inductive properties. Genes Dev 2008; 22(4):543-57.

45. Mohebbipour Laran A, Mirmohammadi R, Rezaei Bana M, Manoochehri S. Hair follicles are viable after delayed FUE procedure. J Cosmet Laser Ther 2015; 3:1-2.

46. Avram MR, Rogers N, Watkins S. Sideeffects from follicular unit extraction in hair transplantation. J Cutan Aesthet Surg 2014; 7(3):177-9.

47. Na GY, Paek SH, Park BC, Kim DW, Lee WJ, Lee SJ, et al. Isolation and characterization of outer root sheath melanocytes of human hair follicles. Br J Dermatol 2006; 155(5):902-9.

48. Yang $\mathrm{R}, \mathrm{Xu} \mathrm{X}$. Isolation and culture of neural crest stem cells from human hair follicles. $\mathrm{J}$ Vis Exp 2013; 6:(74).

49. Seleit I, Bakry OA, Abdou AG, Dawoud NM. Immunohistochemical evaluation of vitiliginous hair follicle melanocyte reservoir: is it retained? J Eur Acad Dermatol Venereol 2015; 29(3):444-51.

50. Nishimura EK. Melanocyte stem cells: a melanocyte reservoir in hair follicles for hair and skin pigmentation. Pigment Cell Melanoma Res 2011; 24(3):401-10.

51. Tu CX, Jin WW, Lin M, Wang ZH, Man MQ. Levels of TGF- $\beta(1)$ in serum and culture supernatants of CD4(+)CD25 (+) T cells from patients with non-segmental vitiligo. Arch Dermatol Res 2011; 303(9):685-9.

52. Zhou L, Shi YL, Li K, Hamzavi I, Gao TW, Huggins RH, et al. Increased circulating Th17 
cells and elevated serum levels of TGF-beta and IL-21 are correlated with human nonsegmental vitiligo development. Pigment Cell Melanoma Res 2015; 28(3):324-9.

53. Kim DS, Park SH, Park KC. Transforming growth factor-betal decreases melanin synthesis via delayed extracellular signalregulated kinase activation. Int $\mathrm{J}$ Biochem Cell Biol 2004; 36(8):1482-91.

54. Xu D, Yuan R, Gu H, Liu T, Tu Y, Yang $\mathrm{Z}$, et al. The effect of ultraviolet radiation on the transforming growth factor beta 1/ Smads pathway and p53 in actinic keratosis and normal skin. Arch Dermatol Res 2013; 305(9):777-86.

55. He T, Quan T, Fisher GJ. Ultraviolet irradiation represses TGF- $\beta$ type II receptor transcription through a 38-bp sequence in the proximal promoter in human skin fibroblasts. Exp Dermatol 2014; 23(Suppl 1):2-6.

56. Ferguson B, Kunisada T, Aoki H, Handoko HY, Walker GJ. Hair follicle melanocyte precursors are awoken by ultraviolet radiation via a cell extrinsic mechanism. Photochem Photobiol Sci 2015; 14(6):1179-89.

57. Dong D, Chen S, Zhang X, Jin C, Zheng Y, Yang L. Comparison of high-intensity ultraviolet and NB-UVB on the maturation of melanocytes derived from hair follicle neural crest stem cells. Lasers Med Sci 2014 ;29(5):1649-54.

58. Goldstein NB, Koster MI, Hoaglin LG, Spoelstra NS, Kechris KJ, Robinson SE, et al. Narrow band ultraviolet B treatment for human vitiligo is associated with proliferation, migration, and differentiation of melanocyte precursors. J Invest Dermatol 2015; 135(8):2068-76.

59. Khunger N, Kathuria SD, Ramesh V. Tissue grafts in vitiligo surgery-past, present, and future. Indian J Dermatol 2009; 54(2):150-8.
60. Parsad D, Gupta S. Standard guidelines of care for vitiligo surgery. Indian J Dermatol Venereol Leprol 2008; 74:37-45.

61. Rusfianti M, Wirohadidjojo YW. Dermatosurgical techniques for repigmentation of vitiligo. Int J Dermatol 2006; 45(4):411-7.

62. Rassman WR, Bernstein RM, McClellan R, Jones R, Worton E, Uyttendaele H. Follicular unit extraction: minimally invasive surgery for hair transplantation. Dermatol Surg 2002; 28(8):720-8.

63. Sethi P, Bansal A. Direct hair transplantation: a modified follicular unit extraction technique. J Cutan Aesthet Surg 2013; 6(2):100-5.

64. Sacchidanand S, Thakur P, Purohit V, Sujaya, SN. Follicular unit extraction as a therapeutic option for vitiligo. J Cutan Aesthet Surg 2013; 6(4):229-31.

65. Aziz Jalali $M$, Jafari $B$, Isfahani $M$, Nilforoushzadeh MA. Treatment of segmental vitiligo with normal-hair follicle autograft. Med J Islam Repub Iran 2013; 27(4):210-4.

66. Chouhan K, Kumar A, Kanwar A. Body hair transplantation in vitiligo. J Cutan Aesth Surg 2013; 6(2):111-2.

67. Mapar MA, Safarpour M, Mapar M, Haghighizadeh MH. A comparative study of the mini-punch grafting and hair follicle transplantation in the treatment of refractory and stable vitiligo. J Am Acad Dermatol 2014; 70(4):743-7.

68. Kumar A, Mohanty S, Sahni K, Kumar R, Gupta S. Extracted hair follicle outer root sheath cell suspension for pigment cell restoration in vitiligo. J Cutan Aesthet Surg 2013; 6(2):121-5.

69. Mohanty S, Kumar A, Dhawan J, Sreenivas V, Gupta S. Noncultured extracted hair follicle outer root sheath cell suspension for transplantation in vitiligo. $\mathrm{Br} \mathrm{J}$ Dermatol 2011; 164(6):1241-6. 